\title{
'Bakirtzeika': A Greek Sweet Cherry Cultivar
}

\author{
Ioannis Chatzicharissis, Konstantinos Kazantzis, and \\ Thomas Sotiropoulos ${ }^{1}$
}

Pomology Institute (National Agricultural Research Foundation), P.O. Box 122, Naoussa, 59200, Greece

\section{Nikolaos Koutinas}

Alexander Technological Educational Institute of Thessaloniki, Department of Crop Production. P.O. Box 141, 57400, Thessaloniki, Greece

Additional index words. Prunus avium, cultivar description, fruit breeding

'Bakirtzeika' sweet cherry (Prunus avium L.) is a mid-late season, high-quality cultivar that matures $1 \mathrm{~d}$ earlier than 'Germersdorfer'. The trees require cross-pollination. Productivity and mean fruit weight of 'Bakirtzeika' were higher than 'Germersdorfer'. The fruit of 'Bakirtzeika' are large, symmetrical, and heart-shaped. Fruit of 'Bakirtzeika' are juicy, sour-sweet in taste when mature, and have good eating quality. The total soluble solids content of 'Bakirtzeika' was higher than 'Germersdorfer', whereas firmness was not different between the cultivars.

\section{Origin}

'Bakirtzeika' is a local Greek sweet cherry cultivar that was discovered as a chance seedling in 1986. The same year, the cultivar was included in an official trial and evaluated in the experimental orchard of the Greek Pomology Institute located in Naoussa (northern Greece, long. $22^{\circ} 12^{\prime} 0^{\prime \prime} \mathrm{E}$; lat. $40^{\circ} 29^{\prime} 04^{\prime \prime} \mathrm{N}$; elevation $225 \mathrm{~m}$ ). The objective of this research was to provide information about the new Greek sweet cherry cultivar Bakirtzeika comparing it with the cultivar Germersdorfer that matures during the same period.

\section{Description}

The experimental trees were grafted on a wild cherry seedling rootstock (mazzard) (Prunus avium L.), trained in a typical vase form, and planted at a distance of $6 \times 6 \mathrm{~m}$ apart. The soil at the experimental orchard at a depth of 0 to $80 \mathrm{~cm}$ was characterized as clay loam, slightly alkaline ( $\mathrm{pH} 7.50)$, with low electrical conductivity $\left(0.65 \mathrm{mS} \cdot \mathrm{cm}^{-1}\right)$ and low organic matter $(0.78 \%)$ and $\mathrm{CaCO}_{3}$ $(1.9 \%)$ content. Annual rainfall ranges from 600 to $800 \mathrm{~mm}$. The mean maximum temperature of the experimental area is $38^{\circ} \mathrm{C}$ in July, whereas the minimum temperature is $-7^{\circ} \mathrm{C}$ in January. Trees were irrigated by means of microsprinklers. Application of nutrients was based on leaf and soil analyses data. With

Received for publication 17 Mar. 2011. Accepted for publication 17 May 2011.

${ }^{1}$ To whom reprint requests should be addressed; e-mail thosotir@otenet.gr. regard to foliar application of nutrients, boron was applied annually at the pre-bloom stage, zinc on newly developed leaves after budbreak, and calcium two to three times before harvest.

Trees of 'Bakirtzeika' are vigorous (more vigorous than 'Germersdorfer') with an upright growth habit. Flower buds are conical. The leaves are large, elliptical in shape, and have dentate margins. Blade length and width of 'Bakirtzeika' were larger than 'Germersdorfer' (Table 1). The nectaries are kidneyshaped and orange-red in color. Leaf fall of 'Bakirtzeika' and 'Germersdorfer' starts on 27 and 26 Nov., respectively (means based on 10 years' data). The flower density of 'Bakirtzeika' is high, similar to 'Germersdorfer'. Both cultivars have an average of three flowers per flowering bud. Flowering of cultivars Bakirtzeika and Germersdorfer starts on 9 and 11 Apr., respectively (means based on 10 years' data). The trees require cross-pollination. The S-locus genotype of 'Bakirtzeika' as determined by polymerase chain reaction is $\mathrm{S}_{3} \mathrm{~S}_{4}$ (Ganopoulos et al., 2010), whereas that of 'Germersdorfer' is $\mathrm{S}_{3} \mathrm{~S}_{12}$ (Bekefi, 2006). Regarding S-locus genotype incompatibility classification in sweet cherry, 'Bakirtzeika' belongs to Group III, whereas 'Germersdorfer' belongs to Group XXII (Bekefi, 2006).

Productivity data of 10 years reported are means of nine trees (three replications $\times$ three trees) per cultivar grafted on mazzard rootstock (means were based on data collected from when the trees were 5 years old to when they were 15 years of age) analyzed as a randomized complete block design. All other fruit characteristics reported were based on a random sample of 300 fruits selected from the experimental trees in each year. Leaf characteristics reported were based on a random sample of 100 leaves selected from each experimental tree in each year. The significance of the differences between means was evaluated using Fisher's $t$ test analysis of variance at $P<0.05$ carried out in SPSS Version 17 (SPSS Inc., Chicago, IL).

Fruit of 'Bakirtzeika' mature $1 \mathrm{~d}$ later than 'Germersdorfer', 5 June for 'Bakirtzeika' and 4 June for 'Germersdorfer' (means based on 10 years' data). Mature fruit of the two cultivars were evaluated immediately after harvest. Productivity of 'Bakirtzeika' was higher than 'Germersdorfer' when grafted on mazzard rootstock, 100 and $80 \mathrm{~kg} /$ tree, respectively. The fruit of 'Bakirtzeika' are large, symmetrical, and heart-shaped (Fig. 1; Table 2) (Schmidt et al., 1985). Mean fruit weight of 'Bakirtzeika' was higher than 'Germersdorfer', whereas fruit length, width, and thickness were not different between the cultivars. Our results are in accordance with those of Albertini and Strada (2001) and Fajt et al. (2008) who reported that fruit weight of 'Germersdorfer' averaged $9.3 \mathrm{~g}$. 'Bakirtzeika' fruit are attractive with a bright red color. L, a, and chroma color parameters were measured by a chromatometer (Minolta CR-200, Tokyo, Japan). L and a parameters of 'Germersdorfer' were higher than 'Bakirtzeika', whereas chroma was not different between cultivars. The pedicel length of 'Bakirtzeika' is $\approx 5.3 \mathrm{~cm}$. Fruit of 'Bakirtzeika' are juicy with a sour-sweet taste when mature and have good eating quality. Total soluble solids content (measured with the Atago PR-1 electronic refractometer; Atago Co. Ltd., Tokyo, Japan) of 'Bakirtzeika' was higher than 'Germersdorfer' (Table 2). Our results are in accordance with those of Albertini and Strada (2001) and Fajt et al. (2008) who reported that total soluble solids of 'Germersdorfer' was 14\% Brix. Firmness (measured with an Effegi penetrometer 6-mm tip; Effegi, Milan, Italy) was not different between the two cultivars. Stone shape of 'Bakirtzeika' is ovoid, whereas that of 'Germersdorfer' is oblong. Stone length, thickness, and width of 'Bakirtzeika' did not differ from

Table 1. Leaf characteristics of 'Germersdorfer' and 'Bakirtzeika'.

\begin{tabular}{lcc}
\hline Cultivar & Germersdorfer & Bakirtzeika \\
\hline $\begin{array}{c}\text { Length of } \\
\text { blade }(\mathrm{cm})\end{array}$ & $12.20 \mathrm{~b}^{\mathrm{z}}$ & $15.20 \mathrm{a}$ \\
$\begin{array}{c}\text { Width of } \\
\text { blade }(\mathrm{cm})\end{array}$ & $5.68 \mathrm{~b}$ & $6.69 \mathrm{a}$ \\
$\begin{array}{c}\text { Ratio of blade } \\
\text { length/width }\end{array}$ & $2.17 \mathrm{a}$ & $2.27 \mathrm{a}$ \\
$\begin{array}{c}\text { Length of } \\
\text { petiole }(\mathrm{cm})\end{array}$ & $5.18 \mathrm{a}$ & $5.36 \mathrm{a}$ \\
$\begin{array}{c}\text { Width of } \\
\text { petiole }(\mathrm{cm})\end{array}$ & $0.15 \mathrm{a}$ & $0.18 \mathrm{a}$ \\
$\begin{array}{c}\text { Number of } \\
\text { nectaries } \\
\text { per leaf }\end{array}$ & $2.00 \mathrm{a}$ & $2.00 \mathrm{a}$ \\
$\frac{\mathrm{z}}{\mathrm{z}}$ Means followed by the same letter in the same row
\end{tabular}
are not significantly different (Fisher's F; $P<0.05$ ).

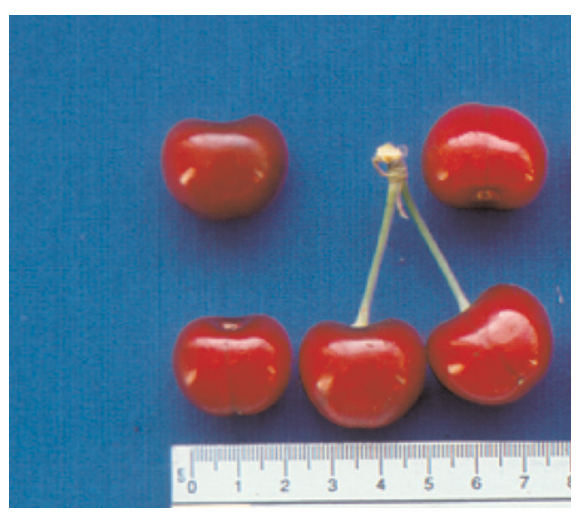

Fig. 1. Fruits of 'Bakirtzeika'. 
Table 2. Fruit characteristics of 'Germersdorfer' and 'Bakirtzeika'.

\begin{tabular}{lcr}
\hline Cultivar & Germersdorfer & Bakirtzeika \\
\hline Fruit length $(\mathrm{mm})$ & $23.50 \mathrm{a}^{\mathrm{z}}$ & $22.90 \mathrm{a}$ \\
Fruit width $(\mathrm{mm})$ & $26.50 \mathrm{a}$ & $28.10 \mathrm{a}$ \\
Fruit thickness $(\mathrm{mm})$ & $22.20 \mathrm{a}$ & $23.60 \mathrm{a}$ \\
Pedicel length $(\mathrm{cm})$ & $6.20 \mathrm{a}$ & $5.30 \mathrm{~b}$ \\
Fruit weight $(\mathrm{g})$ & $9.50 \mathrm{~b}$ & $12.10 \mathrm{a}$ \\
$\mathrm{L}$ & $28.30 \mathrm{a}$ & $23.40 \mathrm{~b}$ \\
$\mathrm{a}$ & $19.20 \mathrm{a}$ & $16.50 \mathrm{~b}$ \\
chroma & $20.10 \mathrm{a}$ & $20.40 \mathrm{a}$ \\
Fruit firmness $\left(\mathrm{kg} / \mathrm{cm}^{2}\right)$ & $0.62 \mathrm{a}$ & $0.64 \mathrm{a}$ \\
Total soluble solids $(\%$ Brix $)$ & $14.90 \mathrm{~b}$ & $18.50 \mathrm{a}$ \\
\hline${ }^{2}$ Means followed by the same letter in the same row are not significantly different (Fisher's F; $\left.P<0.05\right)$.
\end{tabular}

Table 3. Stone characteristics of 'Germersdorfer' and 'Bakirtzeika'

\begin{tabular}{lcc}
\hline Cultivar & Germersdorfer & Bakirtzeika \\
\hline Stone length $(\mathrm{mm})$ & $12.20 \mathrm{a}^{\mathrm{z}}$ & $10.70 \mathrm{a}$ \\
Stone width $(\mathrm{mm})$ & $9.80 \mathrm{a}$ & $8.90 \mathrm{a}$ \\
Stone thickness $(\mathrm{mm})$ & $7.30 \mathrm{a}$ & $7.00 \mathrm{a}$ \\
Stone weight $(\mathrm{g})$ & $0.62 \mathrm{a}$ & $0.50 \mathrm{~b}$ \\
Ratio of stone/fruit weight & $0.07 \mathrm{a}$ & $0.04 \mathrm{~b}$ \\
\hline z & &
\end{tabular}

${ }^{2}$ Means followed by the same letter in the same row are not significantly different (Fisher's F; $P<0.05$ ).

'Germersdorfer', whereas stone weight and the ratio of stone/fruit weight were lower in 'Bakirtzeika' (Table 3). Macroscopical observations revealed that 'Bakirtzeika' showed the same susceptibility with 'Germersdorfer' to the main cherry tree diseases. Furthermore, in the soil-climatic conditions of the experimental orchard, both cultivars showed good resistance to cracking induced by rainfall before harvest, which is of major importance for selecting a cultivar (Albertini and Strada, 1996).

In conclusion, 'Bakirtzeika' is a promising sweet cherry cultivar. Its ecological adaptation in all the areas in central and northern Greece where the trees were planted was very good.

\section{Availability}

'Bakirtzeika' sweet cherry was registered in the official list of cultivars of the Greek Ministry of Agriculture in 1991 and virusfree plants are presently available from the Greek Pomology Institute (R.R. Station 38, 59200, Naoussa, Greece). We have not yet applied for protection of this cultivar according to UPOV (International Union for the Protection of New Varieties of Plants) guidelines.

\section{Literature Cited}

Albertini, A. and G.D. Strada. 1996. Monografia di cultivar di ciliegio dolce. Istituto Sperimentale per la Frutticoltura, Rome, Italy.

Albertini, A. and G.D. Strada. 2001. Monografia di cultivar di ciliegio dolce e acido. Istituto Sperimentale per la Frutticoltura, Rome, Italy.

Bekefi, Z. 2006. Review of sweet and sour cherry incompatibility. Intl. J. Hort. Sci. 12:111-116.

Fajt, N., E. Komel, and V. Usenik. 2008. Promising sweet cherry cultivars in Slovenia. Acta Hort. 795:349-356.

Ganopoulos, I., A. Argiriou, and A. Tsaftaris. 2010. Determination of self-incompatible genotypes in 21 cultivated sweet cherry cultivars in Greece and implications for orchard cultivation. J. Hort Sci. Biotechnol. 85:444-448.

Schmidt, H., J.V. Christensen, R. Watkins, and R.A. Smith. 1985. Cherry descriptor list. IBPGR Secretariat, Rome, Italy. 